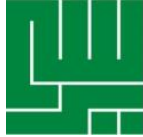

\title{
Nilai Kerja (Work Values) dan Adaptabilitas Karier Peserta Didik Kelas IX di Depok, Jawa Barat
}

\section{Work Values and Career Adaptability of $9^{\text {th }}$ Grade Students in Depok, West Java}

\author{
Linda Primana ${ }^{1}$, Amanda Kristanti Permadi ${ }^{2}$ \\ ${ }^{I}$ Fakultas Psikologi, Universitas Indonesia, Depok, Jawa Barat, Indonesia \\ ${ }^{2}$ Fakultas Psikologi, Universitas Indonesia, Depok, Jawa Barat, Indonesia
}

KATA KUNCI KEYWORDS

ABSTRAK
ABSTRACT
Nilai kerja, adaptabilitas karir, peserta didik kelas IX, remaja. work values, career adaptability, junior high school students, adolescence

Berdasarkan Kurikulum 2013, peserta didik SMA diberikan kesempatan untuk memilih peminatannya di kelas X. Dengan demikian sebelum peserta didik lulus SMP, mereka diharapkan sudah memiliki wawasan tentang nilai-nilai dari suatu pekerjaan (work values) sebagai dasar pertimbangannya dalam merencanakan karier masa depannya. Tujuan penelitian ini adalah untuk mengetahui peran work values terhadap adaptabilitas karier peserta didik kelas IX. Work values diukur dengan menggunakan The Work Values Scale (Ye, 2015) dan adaptabilitas karier diukur dengan menggunakan alat ukur Career AdaptAbilities Scale (CAAS) (Savickas \& Porfeli, 2012). Partisipan penelitian ini adalah 569 peserta didik kelas IX SMP di Depok, Jawa Barat. Hasil olah data statistik Pearson Correlation menunjukkan terdapat hubungan yang positif dan signifikan antara work values dan adaptabilitas karier. Work values memberikan kontribusi sebesar $21 \%\left(R^{2}\right)$ terhadap variasi adaptabilitas karier. Penelitian ini memberikan masukan tentang pentingnya wawasan peserta didik mengenai work values atau nilai suatu pekerjaan dimulai sejak mereka berada di SMP, agar mereka dapat dengan percaya diri menentukan pilihan peminatannya di SMA.

Based on the 2013 curriculum, senior high school students have the opportunity to learn another subjects from the major subject they interested on grade $X^{\text {th }}$. Students are expected to be more prepared and adaptive for their career in the future, which influenced by their knowledge about work values. The purpose of the present study was to investigate the role of work values on career adaptability of IX ${ }^{\text {th }}$ grade students. The Work Values Scale (Ye, 2015) was used to measure work values and Career Adapt-Abilities Scale (CAAS) (Savickas \& Porfeli, 2012) was used to measure career adaptability. Participants of the study were 569 of IX ${ }^{\text {th }}$ grade state junior high school students in Depok, West Java. Results of Pearson Correlation showed that there was a positive and significant correlation between work values and career adaptability. Work values contribute $21 \%\left(R^{2}\right)$ to career adaptability variations. This study highlighted the importance of work values for junior high school students, so that they would be able to decide confidently their major interest in high school. 


\section{PENDAHULUAN}

Individu dalam menjalani karier dalam hidupnya membutuhkan penyesuaian diri untuk dapat menghadapi perubahan baik yang berasal dari dalam maupun dari lingkungan di luar dirinya agar memeroleh kesuksesan dan kepuasan hidup (Brown \& Lent, 2016). Dalam hal ini, kemampuan adaptabilitas karier, terutama pada remaja, menjadi penting dimiliki untuk penyesuaian diri yang lebih baik di lingkungan sosial dan untuk kesejahteraan hidupnya (Skorikov \& Vondracek, 2007). Adaptabilitas karier individu mencakup kemampuan dan keterampilan psikososialnya untuk membuat perubahan di dalam diri dan memenuhi tuntutan dari lingkungan dalam mengelola tugas-tugas, menghadapi masa transisi, dan traumatrauma yang berhubungan dengan eksplorasi karier, pemilihan karier, dan penyesuaian diri dalam pekerjaan (Savickas, 2011). Dasar dari teori adaptabilitas karier adalah teori kematangan karier (Super, 1990) yang melalui berbagai penelitian ditemukan bahwa kematangan karier dianggap kurang dapat menjelaskan perkembangan karier pada tahapan orang dewasa (Savickas, 1997).

Eksplorasi karier dimulai sejak masa remaja di saat individu menginjakkan kakinya di Sekolah Menengah Pertama (SMP) (Savickas, 2002). Sekolah memegang peranan penting dalam membina dan menanamkan aspirasi karier peserta didiknya, terutama di SMP. Selama tiga tahun menjalani pembelajaran di tingkat pendidikan ini, peserta didik diharapkan mempersiapkan dirinya menentukan minatnya untuk kelanjutan studinya di Sekolah Menengah Atas (SMA). Peserta didik setidaknya sudah mengetahui akan memilih bidang Ilmu Pengetahuan Sosial (IPS), Ilmu Pasti Alam (IPA), atau Bahasa.

Pemilihan jurusan di SMA, saat ini berbeda dari waktu-waktu sebelumnya. Dimana penjurusan ditentukan pada saat peserta didik naik ke kelas XI. Sejak Tahun
Ajar 2014, kurikulum 2013 mengalami perubahan untuk penjurusan di SMA (Peraturan Menteri Nomor 69 Tahun 2013). Peserta didik dikelompokkan sesuai minatnya, bukan berdasarkan jurusan. Mereka diminta menentukan minatnya terhadap bidang ilmu yang akan ditekuninya, IPS, IPA, atau Bahasa. Penentuan peminatan didasarkan atas nilai rapor SMP, nilai Ujian Nasional SMP, rekomendasi guru bimbingan dan konseling di SMP, hasil tes penempatan, dan hasil tes minat dan bakat oleh Psikolog (Kompasiana, 2013).

Adanya tuntutan untuk menentukan minat selepas SMP dan berbagai masalah terkait tugas perkembangan psikologis peserta didik di masa remaja ini, antara lain menghadapi transisi dari SMP ke SMA, proses pencarian jati diri, eksplorasi karier, maka kemampuan adaptabilitas karier peserta didik SMP menjadi hal yang penting untuk diperhatikan. Oleh karena itu, melalui penelitian ini ingin dijawab salah satu pertanyaan penelitian ini tentang "Bagaimana gambaran adaptabilitas karier peserta didik kelas IX?"

Peserta didik dapat beradaptasi dengan mudah memenuhi tuntutan lingkungan di mana ia berada jika ia peduli, memiliki kontrol, memiliki keingintahuan terhadap masa depan vokasionalnya, dan memiliki kepercayaan diri bahwa ia dapat meraih apa yang menjadi tujuan hidupnya (Savickas \& Porfeli, 2012). Perencanaan dan eksplorasi individu terhadap kariernya di masa mendatang merupakan salah satu bentuk kemampuan penyesuaian diri individu terhadap pemilihan kariernya pada masa transisi. Penelitian-penelitian yang menginvestigasi faktor-faktor yang memengaruhi perkembangan dan pemilihan karier, menemukan work values merupakan salah satu faktor terpenting yang dapat memengaruhi perkembangan, pemilihan karier, dan kepuasan karier dalam diri individu (Hirschi, 2010).

Work values merupakan konstruk utama dalam penentuan pemilihan karier (Rounds \& Jin, 2013). Work values 
merujuk kepada hal atau nilai-nilai kerja yang dianggap penting bagi individu dalam pekerjaannya (Lyon, Higgins, \& Duxbury, 2010). Work values merupakan cerminan dari kebutuhan atau tujuan hidup yang dicari individu untuk meraih kepuasan hidup yang diperolehnya dari pekerjaan yang mereka tekuni (Super \& Sverko, 1995). Teori dan studi-studi mengenai work values membedakan antara intrinsic work values dan extrinsic work values (Ros, Schwartz, \& Surkiss, 1999). Intrinsic work values merujuk kepada nilai-nilai yang berhubungan dengan konten dari pekerjaan, seperti kompetensi yang diperlukan dari pekerjaan, minat, harga diri, status, dan kebutuhan aktualisasi diri. Di lain pihak, extrinsic work values merujuk kepada nilainilai yang berhubungan dengan segala sesuatu yang diperoleh dari bekerja yang sifatnya berkaitan dengan keadaan ekonomi individu, seperti prestise, prestasi kerja, dan pencapaian target kerja/promosi jabatan (Lyon, Higgins, \& Duxbury, 2010).

Pada peserta didik SMP kelas IX, pengetahuan atau informasi yang dimiliki mengenai work values akan sangat membantunya dalam menentukan dan memilih peminatannya pada saat memasuki SMA. Sebagai contoh, seorang peserta didik SMP kelas IX, sebut saja Yana, memiliki kemampuan dan prestasi di bidang IPS, memiliki minat terhadap kejadian-kejadian di lingkungan sosialnya. Nilai-nilainya di rapor juga memperlihatkan bahwa ia memiliki kemampuan yang baik dalam bidang ilmu sosial. Bila ia telah banyak melakukan eksplorasi mencari informasi tentang pekerjaan-pekerjaan apa saja kiranya yang dapat memberikan kepuasan bagi dirinya kelak di kemudian hari, maka akan mudah baginya untuk menentukan minat saat masuk ke SMA yaitu peminatan IPS. Berbeda halnya dengan peserta didik lain, sebut saja Ari, yang berprestasi di bidang IPA, namun masih belum tahu akan memilih bidang peminatan apa pada saat SMA kelas $\mathrm{X}$ setelah lulus SMP, karena sangat minim informasi mengenai pekerjaan-pekerjaan apa saja yang memungkinkannya untuk berkarier dengan kemampuan yang dimilikinya. Work values dapat membantu peserta didik dalam memilih dan merencanakan kariernya.

Penelitian-penelitian terdahulu menemukan bahwa terdapat hubungan antara intrinsic work values, extrinsic work values dan adaptanilitas karier (Hirschi, 2010; Lyons et al., 2010). Pada penelitian dengan responden peserta didik SMA dan mahasiswa, ditemukan korelasi yang positif dan signifikan antara intrinsic work values dan kematangan/adaptabilitas karier. Korelasi yang signifikan dan negatif ditemukan dalam hubungan extrinsic work values dan kematangan/adaptabilitas karier, namun dilaporkan dalam penelitian tersebut bahwa hubungannya tidak kuat (Lee, 1997; Post-Kammer, 1987). Hal ini dapat dimengerti dari perspektif teori motivasi, nilai yang dimiliki individu secara intrinsik diasumsikan akan mendorong individu untuk meraih tujuannya (Roberts \& Robin, 2000), dan tidak demikian adanya dengan nilai yang sifatnya ekstrinsik. Oleh karena itu, sangat mungkin bahwa intrinsic work value, memiliki hubungan yang positif dengan perkembangan karier individu secara umum, bukan extrinsic work values (Hirschi, 2010).

Walau sudah banyak penelitian tentang faktor-faktor yang mempengaruhi proses penentuan pemilihan karier pada remaja, penelitian mengenai work values yang merupakan salah satu faktor yang paling penting dalam memengaruhi pemilihan karier pada remaja, masih belum banyak dilakukan (Hirschi, 2010). Pertanyaan penelitian kedua yang ingin dijawab di penelitian ini adalah "Bagaimana gambaran work values peserta didik kelas IX?" Selanjutnya, penelitian ini bertujuan ingin mengetahui peranan work values terhadap adaptabilitas karier peserta didik kelas IX. Hipotesis alternatif yang diajukan dalam penelitian ini adalah: "Terdapat peran work values terhadap adaptabilitas karier peserta didik kelas IX." 


\section{METODE}

Partisipan penelitian ini adalah 569 peserta didik kelas IX dari dua SMP Negeri di Depok, Jawa Barat yang terpilih dengan teknik accidental sampling. Usia rata-rata partisipan adalah 14,7 tahun dan terdiri dari laki-laki sebanyak 226 orang $(39,7 \%)$ dan perempuan sebanyak 343 orang $(60,3 \%)$. Partisipan diminta untuk mengisi kuesioner mengenai work values dan adaptabilitas karier. Sebelum peserta didik mengisi kuesioner, kepada mereka diminta untuk menandatangani lembar persetujuan kesediaannya untuk menjadi responden penelitian ini. Setelah selesai mengisi kuesioner, seluruh partisipan diberi token sebagai tanda terima kasih telah berpartisipasi dalam penelitian ini.

Adaptabilitas karier diukur dengan menggunakan alat ukur Career AdaptAbilities Scale (CAAS) yang telah banyak digunakan diberbagai negara (Savickas \& Porfeli, 2012). Skala alat ukur ini terdiri dari 24 aitem dengan lima kategori respon jawaban Skala Likert $(1=$ sangat tidak sesuai; 5 = sangat sesuai). CAAS mencakup empat dimensi konstruk adaptabilitas karier, yaitu career concern, career control, career curiosity, dan career confidence. Untuk penelitian ini, peneliti melakukan adaptasi terhadap skala CAAS dengan menerjemahkannya ke dalam Bahasa Indonesia dan menerjemahkannya kembali ke Bahasa Inggris. Koefisien reliabilitas Alpha Cronbach CAAS adalah 0,89 dan dapat dikatakan baik.

Untuk mengukur work values digunakan The Work Values Scale (Ye, 2015) yang merupakan pengembangan alat ukur Super's Work Values Inventory (Super, 1970) dan Manhardt's Work Values Inventory (Meyer, Irving, \& Allen, 1998). The Work Values Scale terdiri dari 29 aitem yang mencakup dimensi intrinsic work values (14 aitem) dan extrinsic work values (15 aitem) dengan menggunakan 7 kategori respon jawaban Skala Likert $(1=$ sangat tidak penting; $7=$ sangat penting). Uji reliabilitas alat ukur memeroleh koefisien
Alpha Cronbach sebesar 0,86 dan dapat dikatakan baik.

Terhadap kedua alat ukur yang digunakan dalam penelitian ini, peneliti meminta kesedian tiga orang expert judgment untuk menelaah skala alat ukur dan kemudia berdasarkan masukan dari expert judgment dilakukan revisi terhadap kata-kata yang dinilai terlalu sulit untuk dimengerti oleh peserta didik kelas IX.

Pengolahan data dilakukan dengan menggunakan statistik deskriptif untuk mengetahui gambaran jenis kelamin dan usia peserta didik, dan Pearson Correlation untuk menguji hubungan antara work values dan adaptabilitas karier. Selain itu Teknik Analisis Regresi Linier Berganda digunakan untuk mengetahui sumbangan intrinsic values dan extrinsic values terhadap adaptabilitas karier.

\section{HASIL DAN PEMBAHASAN}

Dari Tabel 1 dapat dilihat bahwa ratarata skor adaptabilitas karier peserta didik adalah 3,9 (Skala Likert 1-5) dan rata-rata skor work values adalah 6,0 (Skala Likert 1-7). Dapat dikatakan bahwa peserta didik kelas IX yang menjadi sampel penelitian ini memiliki adaptabilitas karier yang tergolong baik. Selain itu, mereka juga telah memiliki nilai-nilai sehubungan dengan dunia pekerjaan. Yang menarik dan khas dari peserta didik ini adalah bahwa mereka yang saat ini dalam masa remaja memiliki nilai-nilai sehubungan dengan dunia kerja yang lebih bersifat ekstrinsik ketimbang yang intrinsik (rata-rata skor extrinsic work values $=6,3$; intrinsic work values $=5,7$ )

Hasil olah data statistik Pearson Correlation menunjukkan bahwa terdapat korelasi yang positif dan signifikan antara work values dan adaptabilitas karier $(r=$ .45) (Tabel 1). Dengan demikian dapat dikatakan bahwa makin luas wawasan peserta didik tentang nilai-nilai yang dimilikinya tentang dunia kerja, makin baik pula adaptabilitas kariernya. Work values memberikan sumbangan sebesar $21 \%\left(R^{2}=\right.$ .21) terhadap kebervariasian adaptabilitas 
karier peserta didik kelas IX. Dengan demikian hipotesis penelitian ini yang berbunyi "Terdapat peran work values terhadap adaptabilitas karier peserta didik kelas IX" diterima.

Lebih lanjut, untuk mengetahui seberapa besar kontribusi intrinsic values dan extrinsic values terhadap adaptabilitas karier, dilakukan analisis regresi linier berganda. Hasil olah data statistik menunjukkan hanya variabel intrinsic work values yang memberikan sumbangan signifikan terhadap adaptabilitas karier dengan nilai koefisien determinasi $\left(R^{2}\right)$ sebesar 0,21 (Tabel 2). Hal ini menunjukkan bahwa variasi dari adaptabilitas karier dapat dijelaskan sebesar $21 \%$ oleh intrinsic work values, sementara 79\% ditentukan oleh faktor lain. Dengan perkataan lain, adaptabilitas karier peserta didik kelas IX hanya dipengaruhi oleh nilainilai yang sifatnya intrinsik terhadap dunia kerja.

Tabel 1

Mean, Standard Deviation, dan Korelasi Work Values dan Adaptabilitas Karier

\begin{tabular}{lcc}
\hline Skala & $M(S D)$ & Adaptabilitas Karier \\
\hline Adaptabilitas Karier & $3.9(.4)$ & - \\
Work Values & $6.0(.5)$ & $.45^{* *}$ \\
Intrinsic Work Values & $5.7(.6)$ & $.46^{* *}$ \\
Extrinsic Work Values & $6.3(.5)$ & $.37^{* *}$ \\
\hline
\end{tabular}

$\mathrm{n}=569 ; * * p<.01$.

Tabel 2

Regresi Work Values terhadap Adaptabilitas Karier

\begin{tabular}{lccc}
\hline Work Values & $R^{2}$ & $\beta$ & $p$ \\
\hline Intrinsic Work Values & $.21^{*}$ & $.38^{* * *}$ & .000 \\
Intrinsic dan Extrinsic Work Values & $.21^{*}$ & $.46^{* * *}$ & .000 \\
\hline Note: Variabel terikat: Adaptabilitas Karier & & \\
& $* p<0.05, * * * p<.001$.
\end{tabular}

Dari dua dimensi work values yang diteliti, intrinsic work values memberikan sumbangan yang signifikan terhadap adaptabilitas karier. Dari Tabel 2 dapat diketahui bahwa koefisien regresi menunjukkan nilai yang signifikan $(\beta=$ $0.38, p<0.001)$. Dengan demikian hanya nilai-nilai yang sifatnya intrinsik terhadap dunia kerja yang memberikan kontribusi kepada adaptabilitas karier pada sampel penelitian ini, yaitu peserta didik kelas IX.

Pembahasan hasil penelitian dimulai dari pertanyaan awal penelitian yang bertujuan ingin mengetahui gambaran adaptabilitas karier peserta didik kelas IX, mengingat mereka perlu segera menentukan pilihan minatnya pada saat masuk SMA sesuai dengan perubahan di Kurikulum 13. Adaptabilitas karier peserta didik kelas IX penelitian ini tergolong baik. Mereka memiliki kemampuan dan keterampilan psiko-sosial untuk membuat perubahan di dalam diri dan memenuhi tuntutan dari lingkungan dalam mengelola tugas-tugas, menghadapi masa transisi, dan traumatrauma yang berhubungan dengan eksplorasi karier, pemilihan karier, dan penyesuaian diri dalam pekerjaan. Mereka memiliki kemampuan dalam menghadapi dan menyesuaikan diri dalam mengantisipasi tugas-tugas yang sudah diprediksi maupun tidak dapat diprediksi 
terkait bidang karier yang mereka minati (Hirschi, 2010). Pada penelitian ini juga diperoleh informasi bahwa peserta didik kelas IX telah memiliki work values, nilainilai yang dianggap penting atau yang diinginkan dalam kehidupannya dalam bekerja (Lyon, Higgins, \& Duxbury, 2010).

Hasil utama penelitian ini mengungkap adanya hubungan yang positif dan signifikan antara work values dan adaptabilitas karier. Artinya, semakin peserta didik memiliki nilai-nilai yang dianggap penting untuk kariernya dalam bekerja di masa mendatang, semakin baik penyesuaian dirinya dalam menentukan pilihan kariernya. Hasil ini sesuai dengan penelitian sebelumnya yang dilakukan oleh Ye (2015), namun dengan karakteristik partisipan penelitian yang berbeda yaitu mahasiswa di Chinese University. Penelitian work values terhadap peserta didik kelas IX ini telah memperkaya informasi mengenai gambaran pengetahuan remaja tentang nilai-nilai kerja yang dimilikinya yang dapat memengaruhi kemampuan adaptabilitas kariernya. Nilainilai kerja atau work values yang diperoleh peserta didik dari eksplorasi terhadap pekerjaan-pekerjaan memengaruhi kemampuan dan keterampilan psikososialnya untuk membuat perubahan di dalam diri dan memenuhi tuntutan dari lingkungan dalam mengelola tugas-tugas, menghadapi masa transisi, dan menyesuaikan diri dalam menentukan pilihan minat atau karier (Hirschi, 2010). Dapat diasumsikan bahwa peserta didik kelas IX dalam penelitian ini, telah mengetahui bidang ilmu peminatan di SMA selepas mereka lulus dari SMP.

Hasil penelitian ini juga menunjukkan tipe dari work values yang berperan terhadap adaptabilitas karier. Ternyata tidak hanya pada peserta didik SMA dan mahasiswa saja intrinsic work values berperan terhadap adaptabilitas karier (Hirschi, 2010), tetapi juga pada peserta didik kelas IX penelitian ini. Melalui studistudi longitudinal, intrinsic work values memang ditemukan memiliki kecenderungan yang stabil pada masa dewasa muda (18-22 tahun), dan cenderung meningkat pada masa memulai karier, untuk kemudian secara perlahan menurun dan kemudian stabil (Jin \& Rounds, 2012).

Dari gambaran tipe work values yang diperoleh dari penelitian ini, ternyata extrinsic work values memiliki nilai ratarata lebih tinggi dari pada intrinsic work values. Hal ini menunjukkan bahwa para peserta didik kelas IX pada penelitian ini menilai pekerjaan dalam kehidupannya berdasarkan nilai-nilai yang sifatnya ekstrinsik, yang berhubungan dengan keadaan ekonomi individu seperti gaji, status atau jabatan, atau kesempatan untuk promosi jabatan. Namun demikian, pada penelitian ini extrinsic work values tidak ditemukan memiliki hubungan yang signifikan terhadap adaptabilitas karier. Temuan ini tidak sejalan dengan studi terdahulu yang dilakukan oleh Lee (1997) dan Post-Kammer (1987). Dari penelitian mereka tentang kematangan karier, ditemukan korelasi yang negatif dan signifikan dalam hubungan extrinsic work values dan kematangan karier. Hal ini dapat dipahami, seperti yang telah dipaparkan sebelumnya, bahwa baru pada usia sebelum karier dalam bekerja dimulai (18-22 tahun), intrinsic work values cenderung meningkat (Jin \& Rounds, 2012). Nilai-nilai kerja yang dimiliki individu adalah nilai-nilai kerja yang berhubungan dengan aspekaspek yang sifatnya intrinsik, seperti antara lain harga diri, aktualisasi diri, dan kompetensi diri. Kemungkinan hal ini disebabkan perbedaan karakteristik sampel, dimana pada penelitian ini partisipan penelitian adalah peserta didik kelas IX dengan usia 14-15 tahun.

Studi tentang work values masih jarang dilakukan pada sampel kelompok usia remaja (Hirschi, 2010). Penelitian ini memberikan sumbangan temuan sehubungan dengan work values pada remaja, bahwa remaja juga sudah memiliki gambaran tentang nilai-nilai kerja. Hasil penelitian ini juga memperkaya penelitian serupa yang dilakukan Porfeli pada tahun 
2004. Porfeli (2004) meneliti hubungan work values dan pengalaman kerja secara longitudinal pada peserta didik kelas VI, IX, X, dan XII. Dari studinya disimpulkan bahwa remaja sudah memiliki informasi mengenai work values dan pengalaman kerja berperan dalam pembentukan nilainilai kerja individu. Pengalaman kerja akan memengaruhi individu dalam memilih work values yang dianggap penting baginya untuk dipertahankan atau tidak penting untuk dipertahankan. Nilai-nilai kerja yang dimiliki peserta didik di kelas IX saat ini akan berubah sejalan dengan ada atau bertambahnya pengalamannya dalam bekerja.

Di samping ditemukannya hasil yang menarik, penelitian ini memiliki keterbatasan, antara lain yaitu partisipan penelitian ini hanya mewakili peserta didik kelas IX dari SMP negeri di Depok, Jawa Barat. Dengan demikian, hasil penelitian ini tidak dapat digeneralisasikan. Hasil penelitian kemungkinannya akan berbeda bila partisipan dipilih dari SMP negeri dari populasi yang lebih luas dan dari berbagai macam tipe sekolah, seperti SMP swasta, SMP dengan latar belakang agama, dan SMP Nasional Plus. Hal ini didasari oleh temuan bahwa tipe institusi pendidikan berpengaruh secara signifikan terhadap perkembangan work values dan adaptabilitas karier peserta didiknya (Hirschi, 2009). Selain itu, alat ukur yang digunakan dalam penelitian ini, walaupun telah memberikan hasil uji reliabilitas yang dapat dikatakan baik, masih perlu diuji keterhandalannya, karena belum teruji dalam populasi yang besar.

\section{SIMPULAN DAN SARAN}

Penelitian ini bertujuan ingin mengetahui peran work values terhadap adaptabilitas karier peserta didik kelas IX. Berdasarkan hasil yang ditemukan dalam penelitian ini, dapat disimpulkan bahwa terdapat peran yang signifikan dari work values terhadap adaptabilitas karier peserta didik kelas IX. Hasil ini dapat menjadi masukan bagi institusi pendidikan, khususnya di sekolah SMP negeri yang dijadikan sampel penelitian ini, dalam mempersiapkan peserta didik memilih peminatan di SMA kelak. Dalam membina peserta didiknya, sekolah melalui unit Bimbingan dan Konseling dapat memberikan kesempatan kepada peserta didik untuk lebih banyak mengeksplorasi pekerjaan-pekerjaan yang tersedia di dunia pekerjaan yang sesuai dengan minatnya, sehingga mereka dapat dengan percaya diri menentukan pilihan peminatannya di SMA. Dengan memberikan kesempatan kepada peserta didik untuk mengeksplorasi pekerjaan-pekerjaan yang ada, hal ini sekaligus memberi kesempatan kepada mereka untuk mengevaluasi atau memberi value yang berasal dari dalam dirinya sendiri terhadap bidang pekerjaan yang diminati.

Sebagai saran untuk studi lanjutan adalah dilakukan studi serupa di SMP negeri dengan jumlah sampel yang lebih besar di berbagai kota di Indonesia, untuk mendapatkan hasil yang dapat digeneralisasikan. Selain itu, untuk studi komparatif dapat dilakukan studi serupa terhadap berbagai tipe sekolah, seperti SMP swasta nasional, SMP berlatar belakang agama, dan SMP Nasional Plus. Untuk mendapatkan gambaran yang menyeluruh mengenai hubungan antara work values dan adaptabilitas karier, penelitian longitudinal dapat dilakukan untuk mengetahui bagaimana perkembangan work values dapat memengaruhi adaptabilitas karier.

\section{UCAPAN TERIMA KASIH}

Penelitian ini didanai oleh Hibah Publikasi Terindeks Internasional Untuk Tugas Akhir Mahasiswa UI Tahun 2017.

\section{DAFTAR RUJUKAN}

Brown, S. D., \& Lent, R. W. (2016). Vocational psychology: Agency, equity, and well-being. Annual Review of Psychology, 67, 541565. doi:10.1146/annurev-psych122414-033237. 
Hirschi, A. (2009). Career adaptability sevelopment in adolescence: Multiple predictors and effect on sense of power and life satisfaction. Journal of Vocational Behavior, $74(2)$, 145-155. doi:10.1016/j.jvb.2009.01.002

Hirschi, A. (2010). Positive adolescent career development: The role of intrinsic and extrinsic work values. Career Development Quarterly, 58(3), 276-287.

Jin, J. \& Rounds, J. (2012). Stability and change in work values: a metaanalysis of longitudinal studies. Journal of Vocational Behavior, Vol. 80 No. 2, pp. 326-339.

Kompasiana. (2013). Penjurusan di Kelas X SMA yang Dipaksakan. Retrieved from

http://www.kompasiana.com/septia nnugroho/penjurusan-di-kelas- $\mathrm{X}$ sma yangdipaksakan 552fd6ab6ea8347c428b474a.

Lee, H. R. (1997). A study on the career maturity and intrinsic-extrinsic work values of college students. Korean Journal of Counseling \& Psychotherapy, 9, 289-310.

Lyons, S. T., Higgins, C. A., \& Duxbury, L. (2010). Work values: Development of a new three-dimensional structure based on confirmatory smallest space analysis. Journal of Organizational Behavior, 31(7), 969-1002.

Meyer, J. P., Irving, P. G., \& Allen, N.J. (1998), Examination of the combined effects of work values and early work experiences on organizational commitment. Journal of Organizational Behavior, Vol. 19 No. 1, pp. 29-52.

Peraturan Menteri Pendidikan dan Kebudayaan Nomor 69 Tahun 2013

https://akhmadsudrajat.files.wordpr ess.com/2013/06/07-b-salinanlampiran-permendikbud-no-69-th2013-ttg-kurikulum-sma-ma.pdf.
Porfeli, E. J. (2004). A Longitudinal Study of a Developmental-Contextual Model of Work Values During Adolescence (Unpublished master's thesis). The Pennsylvania State University.

Post-Kammer, P. (1987). Intrinsic and extrinsic work values and career maturity of 9th- and 11th grade boys and girls. Journal of Counseling and Development, 65, 420-423.

Roberts, B. W., \& Robins, R. W. (2000). Broad dispositions, broad aspirations: the intersection of personality and major life goals. Personality and Social Psychology Bulletin, 26, 1284-1296.

Ros, M., Schwartz, S. H. \& Surkiss, S. (1999). Basic individual values, work values, and the meaning of work. Applied Psychology - An International Review, Vol. 48 No. 1, pp. 49-71.

Rounds, J. B., \& Jin, J. (2013). Nature, importance and assessment of needs and values, in Brown, S.D. \& Lent, R.W. (Eds). Career Development and Counseling: Putting Theory and Research to Work, (2nd ed., pp. 417-447). Hoboken, NJ: Wiley.

Savickas, M. L. (1997). Career Adaptability: An Integrative Construct for Life-Span, LifeSpace Theory. The Career Decelopment Quarterly, 45(3), 247-259. doi:10.1002/j.21610045.1997.tb00469.x

Savickas, M. L. (2002). Career Construction: A Development Theory of Vocatonal Behavior. In Career Choice and Development (4th ed., pp. 149-205). San Fransisco: Jossey-Bass.

Savickas, M. L., \& Porfeli, E. J. (2012). Career Adapt-Abilities Scale: Construction, reliability, and measurement equivalence across 13 countries. Journal of Vocational 
Behavior, $\quad 80, \quad 661-673$. doi:10.1016/j.jvb.2012.01.011

Savickas, M. L. (2011). Career counseling. Washington, DC: American Psychological Association Books.

Skorikov, V. B., \& Vondracek, F. W. (2007). Positive career orientation as an inhibitor of adolescent problem behaviour. Journal of Adolescence, 30, 131-146.

Super, D. E. (1970). Manual, Work Values Inventory. Chicago: Riverside Publishing Company.

Super, D. E. (1990). A life-span, life-space approach to career development. In D. Brown \& L. Brooks (Eds.), Career choice and development: Applying contemporary theories to practice (2nd ed., pp. 197-262). San Francisco, CA: Jossey-Bass.

Super, D. E., \& Sverko, B. (1995). Life Roles, Values, and Careers, Jossey-Bass, San Francisco, CA. Taylor, P. (2014), The Next America Boomers, Millennials, and the Looming Generational Showdown. New York, NY.: Pew Research Center.

Ye, L. (2015). Work values and career adaptability of chinese university students. Social Behavior and Personality, 43(3), 411-422. doi:10.2224/sbp.2015.43.3.411. 